\title{
Integrated Assessment of the Ecological Status of Bulgarian Lowland and Semi-Mountain Natural Lakes
}

\author{
Gana Gecheva $^{1}$, Lilyana Yurukova ${ }^{2}$, Svetoslav Cheshmedjiev ${ }^{1}$, Emilia Varadinova $^{2}$, \\ Detelina Belkinova ${ }^{1}$
}

${ }^{1}$ Faculty of Biology, Plovdiv University “P. Hilendarski”, Plovdiv, Bulgaria; ${ }^{2}$ Institute of Biodiversity and Ecosystem Research, Bulgarian Academy of Sciences, Sofia, Bulgaria.

Email: yur7lild@bio.bas.bg

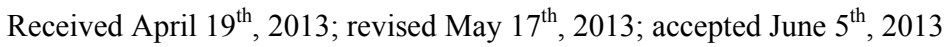

Copyright (C) 2013 Gana Gecheva et al. This is an open access article distributed under the Creative Commons Attribution License, which permits unrestricted use, distribution, and reproduction in any medium, provided the original work is properly cited.

\begin{abstract}
This work focuses on an integrated approach for lake ecological status assessment, elaborated according to the requirements of the European Water Framework Directive (WFD). Data from five lowland and semi-mountain lakes in Bulgaria (Southeast Europe) collected from two years (2011-2012) form the basis for an integrated assessment and the definition of reference conditions. Several metrics were applied in combination, to classify lakes into five ecological status classes. Assemblages of aquatic organisms: phytoplankton, macrophytes and benthic macroinvertebrates, together with 11 supporting physico-chemical parameters were studied. The assessed unique conditions suggested that reference conditions of Bulgarian lakes have natural variability. This first baseline study illustrated specific cases within the lake types that should be assessed in details before providing standardized classification systems in compliance with the requirements of WFD.
\end{abstract}

Keywords: Water Framework Directive; Phytoplankton; Macrophytes; Benthic Macroinvertebrates; Lakes; Water Quality; Reference Condition; Water Assessment

\section{Introduction}

As a result of human activities, natural lakes have been rapidly diminishing in Bulgaria, while man-made water bodies have emerged. Bulgaria is relatively poor in natural lakes: about 250 water bodies of surface area 9500 ha (only $0.09 \%$ of the Bulgarian territory), mostly glacial, coastal and lowland [1]. Accelerated eutrophication process was identified as major threat for the quality of lowland and semi-mountain lakes.

Our research followed the concept that reference conditions are a representation of biological integrity, which can be defined as the ability to support and maintain a balanced, integrated, adaptive community of organisms having a species composition, diversity and functional organization comparable to that of the natural habitat of the region [2]. The Water Framework Directive (WFD) requires an extensive biological evaluation of the water bodies within Europe [3]. On the basis of systematic monitoring of various groups of organisms, a five level ecological classification of lakes is mandatory. Most biological assessment systems are based on the concept of comparing the current biological community to the "re- ference conditions"- - biological conditions associated with no or very low human pressure.

The purpose of the study is to conduct integrated WFD compliant assessment of ecological status of natural lowland and semi-mountain lakes in potential reference conditions. The main objectives were to 1) define the current and the best possible state under optimal but realistic conditions and 2) test the applicability of the existing methods for integrated assessment of lakes in Bulgaria.

\section{Materials and Methods}

\subsection{Study Area}

The studied lakes are located in South Bulgaria (Figure 1). Their surface areas range from about 9 to 82 ha and their depths are in the range of $0.5-11 \mathrm{~m}$.

\subsection{Sampling Techniques: Water Quality Parameters and Biology}

Water quality parameters $(\mathrm{pH}$, electrical conductivity, dissolved oxygen) were measured in situ at the same sites 


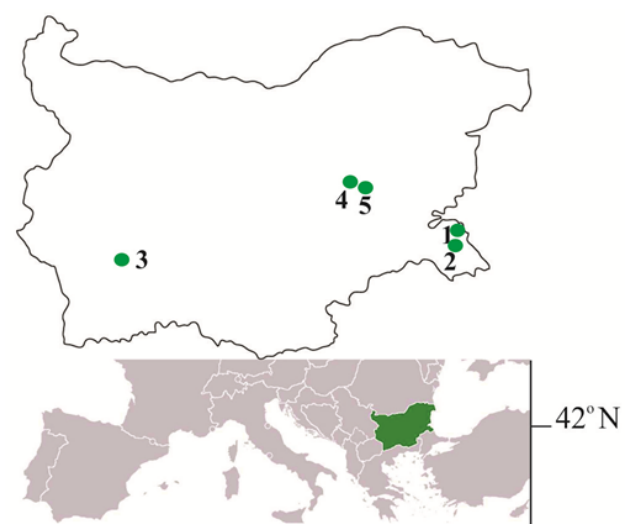

Figure 1. Location of the studied lakes.

as the biological samples. Additionally, N-NH $4, \mathrm{~N}_{4} \mathrm{NO}_{2}$, $\mathrm{N}-\mathrm{NO}_{3}$, phosphate phosphorus, total nitrogen and phosphorus, $\mathrm{COD}$, and $\mathrm{BOD}_{5}$ were analyzed just after sampling on spectrophotometer NOVA 60 (MERCK) following adopted standards: ammonium nitrogen-ISO 7150/1, nitrite and nitrate nitrogen-EN 26777 and ISO 7890-1, total nitrogen (TN)-ISO 11905-1, phosphate

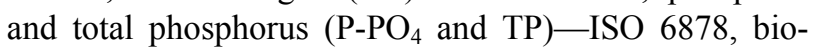
chemical oxygen demand-EN 1899-1,2, and chemical oxygen demand-ISO 15705.

Phytoplankton seasonal (summer and autumn) observations were made during both years. Integrated sampling from the deepest lake zone was carried out by Ruttner batometer. The depth of the euphotic zone was defined as 2.7 times the Secchi depth [4]. In shallow lowland lakes the whole water column was collected. The general taxonomic scheme of Van den Hoek et al. [5] was followed. At least 100 individuals were registered for the most numerous species per sample [6]. The biovolume was determined following geometric form formulas [7], and was transformed into biomass according to Wetzel and Likens [8].

The taxonomic composition and abundance of aquatic macrophytes were recorded as biological metrics in the normative definitions of the ecological status classification in the WFD, Annex 1.2 [3]. All submerged, floating-leafed and helophyte species (Charophytes, Bryophytes and Tracheophytes) were recorded. Sampling was carried out following the recommendations of Schaumburg et al. [9]. The nomenclature accepted in Grolle and Long [10] for liverworts and Hill et al. [11] for mosses was followed. The taxonomy of vascular plants followed Flora Europaea $[12,13]$. The abundance of each species was noted on a five-degree scale $(1=$ very rare, $2=$ infrequent, $3=$ common, $4=$ frequent, $5=$ abundant, predominant) according to Kohler [14].

An adapted version of the multi-habitat sampling method [15], applying different techniques according to EN 27828:2004, ISO 7828-1985 and EN/ISO 9391:1995 was used for benthic macroinvertebrate fauna sampling. For the purpose of comparability of estimates all data were recalculated to $1 \mathrm{~m}^{2}$.

\subsection{Data Evaluation}

The indices for data evaluation were calculated as given below. Assessment results were expressed as the "Ecological Quality Ratio" (EQR) via numerical scale between zero and one, where value one represents (typespecific) reference conditions and values close to zerobad ecological status.

\subsubsection{Definition of Reference Conditions}

Following the requirements of the WFD, the assessment has to reflect the degree of deviation of the current biological community from the reference condition. In Bulgaria, in most cases, no data about lake reference condition exist. However, we found at least reference transects/sites for the studied lake types. The following selection criteria for reference transects/sites were adapted after Pall and Moser [16]:

- pH: within range 6 - 9;

- Dissolved oxygen: within range $7-10 \mathrm{mg} \cdot \mathrm{L}^{-1}$;

- $\mathrm{TP} \leq 0.05 \mathrm{mg} \cdot \mathrm{L}^{-1}$;

- Water level fluctuation: within natural range;

- Transects for macrophytes and sites for phytoplankton and macrozoobenthos samples were selected in areas:

- with no intensive agriculture or settlements;

- in absence of major point sources and tributaries;

- with no (or insignificant) artificial modifications of the shoreline and

- no intensive use for recreation purposes.

\subsubsection{Phytoplankton Metrics}

Four main phytoplankton-based metrics (total phytoplankton biovolume, Algae Group Index, transparency according to Secchi, chlorophyll $a$ ) and 3 additional ones (\% Cyanobacteria, presence of "bloom" and toxic species) were applied. Chlorophyll $a$ concentration was determined spectrophotometrically, after extraction in 90\% ethyl alcohol, following a standard method-ISO 10260: 1992. The intensity of the phytoplankton "bloom" was assessed on the basis of total biovolume on a 5-degree scale: I degree $\leq 2.5 \mathrm{~mm}^{3} \cdot \mathrm{L}^{-1}$; II degree $\approx(2.5-10) \mathrm{mm}^{3} \cdot \mathrm{L}^{-1} ;$ III degree $\approx(10-500) \mathrm{mm}^{3} \cdot \mathrm{L}^{-1} ;$ IV degree $\approx(500-5000)$ $\mathrm{mm}^{3} \cdot \mathrm{L}^{-1} ; \mathrm{V}$ degree ("hyperbloom") $>5000 \mathrm{~mm}^{3} \cdot \mathrm{L}^{-1}$. In calculating \% Cyanobacteria, some species/genera for oligotrophic waters were excluded, focusing on toxic species and eutrophic indicators (following WFD Intercalibration technical report, Part 2-Lakes, Section 3-Phytoplankton biomass metrics Annexes"). The Algae Group Index (AGI, Catálan Index) was calculated for each sample [17]. The interpretation of phytoplankton 
data based on the above metrics followed the classification system for the mesotrophic lake type in Bulgaria [18].

\subsubsection{Macrophytes-Reference Index (RI)}

The macrophyte surveys were carried out once during the main vegetation period (end of June until September). In each sampling site belt transects of 20 - $30 \mathrm{~m}$ width, orthogonal to the shoreline and positioned within an ecologically homogenous section of the littoral were surveyed. The transect number was in correlation to the lake size. At each transect four different depth zones were sampled (0 - $1 \mathrm{~m}, 1-2 \mathrm{~m}, 2-4 \mathrm{~m}$ and $>4 \mathrm{~m})$.

Relative abundance of three different type specific species groups (reference indicators, indifferent taxa, degradation indicators; according to growth depth, some taxa are assigned to different groups) was calculated. The $\mathrm{RI}$ is an expression of the "plant quantity" ratio of typespecific sensitive taxa, dominating at reference conditions, compared to the "plant quantity" of insensitive taxa and is therefore a tool for estimating the deviation of observed macrophyte communities from reference communities. Calculated Reference Index [9,19] was transformed into EQR, where the value of " 1 " reflects the best possible ecological status.

\subsubsection{Benthic Macroinvertebrate Fauna-MZB}

The ecological assessment was based on \% Oligochaeta, an adapted version of the Irish Q-scheme [20,21], adjusted variant-Potamal trophic index-PETI [22] of Feeding type index [23] and total number of taxa. EQR scales relevant to the used metrics were developed for the purposes of national classification system.

\section{Results}

\subsection{Environmental Conditions}

Lake $\mathrm{pH}$ values were neutral to slightly alkaline with average readings between 7.0 and 8.7. Electrical conductivity oscillated between $180-683 \mu \mathrm{S} \cdot \mathrm{cm}^{-1}$, dissolved oxygen between $3.2-12.7 \mathrm{mg} \cdot \mathrm{L}^{-1}$, respectively. As shown in Table 1, significant variation was observed for ammonium nitrogen (17 times), phosphate and total phosphorus (14 and 12 times, respectively) with highest average values at Velyov vir, and COD (above 6 times) with maximum at Choklyovo swamp.

\subsection{Phytoplankton}

High species number was registered varying during the two years between 61 and 80, from 9 taxonomic groups at lowland lakes (Figure 2(A)). Chlorophyceae, Euglenophyceae and Bacillariophyceae had highest species richness. Toxic species were not recorded (Table 2).

Average seasonal biomass had high values and broad ranges: from $7.1-27.4 \mathrm{mg} \cdot \mathrm{L}^{-1}$ (Figure 2(B), Table 2).

Table 1. The characteristics and average levels of water quality parameters, 2011-2012.

\begin{tabular}{|c|c|c|c|c|c|c|c|c|c|c|}
\hline Lake features & \multicolumn{2}{|c|}{ Arkutino } & \multicolumn{2}{|c|}{ Velyov vir } & \multicolumn{2}{|c|}{ Choklyovo } & \multicolumn{2}{|c|}{ Skala 1} & \multicolumn{2}{|c|}{ Skala 2} \\
\hline Lake type & \multicolumn{2}{|c|}{ L5 } & \multicolumn{2}{|c|}{ L5 } & \multicolumn{2}{|c|}{ L4 } & \multicolumn{2}{|c|}{$\mathrm{L} 4$} & \multicolumn{2}{|c|}{ L4 } \\
\hline Altitude & \multicolumn{2}{|c|}{1} & \multicolumn{2}{|c|}{8} & \multicolumn{2}{|c|}{940} & \multicolumn{2}{|c|}{469} & \multicolumn{2}{|c|}{481} \\
\hline Size (ha) & \multicolumn{2}{|c|}{8.9} & \multicolumn{2}{|c|}{13.6} & \multicolumn{2}{|c|}{81.5} & \multicolumn{2}{|c|}{55.4} & \multicolumn{2}{|c|}{9.6} \\
\hline Max depth (m) & \multicolumn{2}{|c|}{0.5} & \multicolumn{2}{|c|}{1.2} & \multicolumn{2}{|c|}{2.5} & \multicolumn{2}{|c|}{11} & \multicolumn{2}{|c|}{8.5} \\
\hline Water quality parameters & 2011 & 2012 & 2011 & 2012 & 2011 & 2012 & 2011 & 2012 & 2011 & 2012 \\
\hline $\mathrm{pH}$ & 7.3 & 7.2 & 7.0 & 7.4 & 7.8 & 7.8 & 8.7 & 8.3 & 7.6 & 8 \\
\hline Conductivity $\left(\mu \mathrm{S} \cdot \mathrm{cm}^{-1}\right)$ & 594 & 683 & 225 & 286 & 262 & 262 & 199 & 180 & 203 & 204 \\
\hline $\mathrm{DO}\left(\mathrm{mg} \cdot \mathrm{L}^{-1}\right)$ & 9.2 & 3.2 & 3.9 & 3.6 & 12.7 & 10.0 & 7.8 & 7.6 & 8.0 & 7.3 \\
\hline $\mathrm{COD}\left(\mathrm{mg} \cdot \mathrm{L}^{-1}\right)$ & 34 & 46 & 24 & 30 & 21.3 & 49 & 10.5 & 9.7 & 7.9 & 8.3 \\
\hline $\mathrm{P}-\mathrm{PO}_{4}\left(\mathrm{mg} \cdot \mathrm{L}^{-1}\right)$ & 0.01 & 0.02 & 0.07 & 0.08 & $<0.01$ & $<0.01$ & $<0.01$ & 0.006 & 0.009 & 0.01 \\
\hline $\mathrm{TP}\left(\mathrm{mg} \cdot \mathrm{L}^{-1}\right)$ & 0.05 & 0.09 & 0.21 & 0.23 & 0 & 0.02 & 0.03 & 0.03 & 0.02 & 0.02 \\
\hline $\mathrm{N}-\mathrm{NH}_{4}\left(\mathrm{mg} \cdot \mathrm{L}^{-1}\right)$ & 0.17 & 0.29 & 0.28 & 0.31 & 0.02 & 0.02 & 0.08 & 0.09 & $<0.01$ & $<0.010$ \\
\hline $\mathrm{N}-\mathrm{NO}_{2}\left(\mathrm{mg} \cdot \mathrm{L}^{-1}\right)$ & $<0.004$ & $<0.004$ & $<0.004$ & $<0.004$ & 0.004 & 0.002 & $<0.004$ & $<0.004$ & $<0.004$ & $<0.004$ \\
\hline $\mathrm{N}-\mathrm{NO}_{3}\left(\mathrm{mg} \cdot \mathrm{L}^{-1}\right)$ & 0.06 & 0.09 & $<0.04$ & $<0.04$ & $<0.2$ & $<0.05$ & $<0.04$ & $<0.04$ & $<0.04$ & $<0.04$ \\
\hline $\mathrm{TN}\left(\mathrm{mg} \cdot \mathrm{L}^{-1}\right)$ & 1.8 & 2.6 & 1.5 & 2.0 & $<0.5$ & 1.1 & $<1.0$ & $<1.0$ & $<1.0$ & $<1.0$ \\
\hline
\end{tabular}

Legend: DO: Dissolved oxigen; COD: Chemical oxygen demand; $\mathrm{BOD}_{5}$ : Biochemical oxygen demand; $\mathrm{P}-\mathrm{PO}_{4}$ : phosphate phosphorus; TP: Total phosphorus; $\mathrm{N}-\mathrm{NH}_{4}$ : Ammonium nitrogen; $\mathrm{N}-\mathrm{NO}_{2}$ : Nitrite nitrogen; $\mathrm{N}_{-} \mathrm{NO}_{3}$ : Nitrate nitrogen; TN: Total nitrogen. 


$\begin{array}{lll}\text { ¿Cyanobacteria } & \text { - Chlorophyceae } & \text { Zygnemaphyceae } \\ \text { ¿Chrysophyceae } & \text { Xanthophyceae } & \text { Bacillariophyceae } \\ \text { Euglenophyceae } & \text { Dinophyceae } & \text { Cryptophyceae }\end{array}$

A. Lowland lakes - species number \%

\begin{tabular}{|c|c|c|c|c|c|}
\hline Arkutino 2011 (61) & 10.3 & 35.4 & 9.3 & 10.3 & 18.6 \\
\hline Arkutino 2012 (65) & 14.1 & 33.3 & 5.3 & 15.1 & 17.6 \\
\hline Velyov vir 2011 (76) & 13.8 & 31.1 & 6.9 & 19 & 21.1 \\
\hline elyov vir $2012(80)$ & 12.2 & 29.5 & .17 .4 & 22.7 & 16. \\
\hline
\end{tabular}

C. Semi-mountains lakes - species number \%

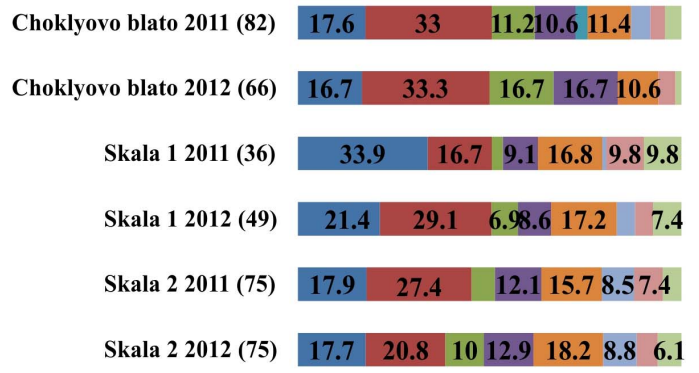

B. Lowland lakes - biomass \%

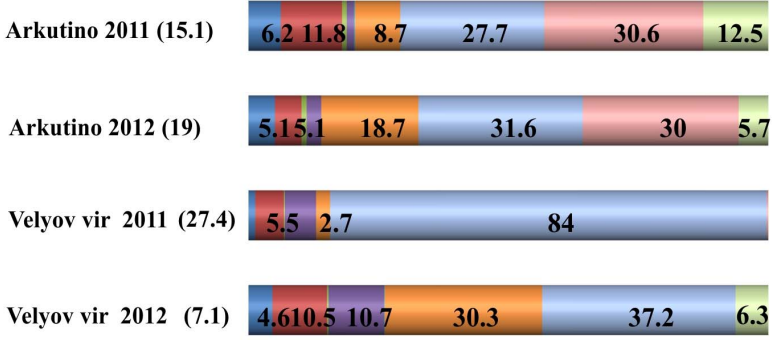

D. Semi-mountains lakes - biomass \%

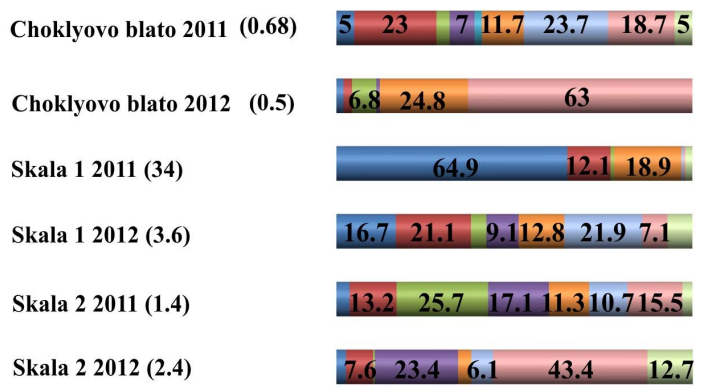

Figure 2. Relative abundance of phytoplankton based on taxonomic groups (mean seasonal values). In parentheses: total species number and total biomass.

Euglenophyceae dominated at both lowland lakes. Euglenoids species represented $3 / 4$ of the biomass at Velyov vir during 2011. An intense bloom of Euglena proxima Dang. (III degree), Trachelomonas armata (Ehr.) Stein (II degree), T. wislouchii Skw. (II degree) was observed in July, 2011. The bloom period faded at the end of the summer, but still seasonal biomass was considerable $\left(27.4 \mathrm{mg} \cdot \mathrm{L}^{-1}\right)$. In quantitative aspect, phytoplankton development was lower during $2012\left(7.1 \mathrm{mg} \cdot \mathrm{L}^{-1}\right)$, as well as biomass had a rather even distribution between Euglenophyceae (37.2\%), Bacillariophyceae (30.3\%), Chrysophyceae (10.7\%) and Chlorophyceae (10.5\%). Noted blooms were less intense than 2011 blooms: Euglena hemichromata Skuja (II degree), T. armata (I degree) and diatom algae Rhopalodia gibba (Ehr.) O. Müll (I degree).

Average seasonal biomass during the two years of observations varied between $15.1-19.0 \mathrm{mg} \cdot \mathrm{L}^{-1}$ at Arkutino Lake and had similar to Velyov vir taxonomic group distribution (Figure 2(B), Table 2). In addition to Euglenophyceae $(31.6 \%)$ as dominants during 2012 were represented Dinophyceae (30.0\%), Bacillariophyceae (18.6\%), and Cryptophyceae (12.5\%) in 2011. Blooms were noticed to be less intense, from Euglenoids and Dinoflagellates: I and II degree during both years. Species E. proxima Dang., Strombomonas urceolata (Stokes) Defl.,
T. volvocinopsis Swir., Peridinium umbonatum F. Stein and Gymnodinium sp. were in bloom concentrations in 2011, while in 2012 E. proxima, P. umbonatum, Gymnodinium sp. were accompanied by $P$. inconspicuum Lemm., T. abrupta (Svirenko) Deflandre, Lepocinclis globula Perty and L. caudata A. M. Cunha. Bloom periods were interrupted at the end of September.

Average chlorophyll $a$ values were high and varied accordingly to the seasonal biomass from 12.6 to 56.7 $\mu \mathrm{g} \cdot \mathrm{L}^{-1}$. The rest metrics had low values and slight variation: \% Cyanobacteria between 0.1 - 0.6, Catalán Index 0.4 - 1.1, transparency $0.28-0.54 \mathrm{~m}$ (Table 2).

Between 36 and 82 phytoplankton species were recorded at semi-mountain lakes during two years, belonging to 9 taxonomic groups (Figure 2(C)). Choklyovo swamp (average 74 species) and Skala 2 Lake (75 species) were with high species richness, while Skala 1 Lake had considerably lower number of species (43). Chlorophyceae $(33.2 \%)$, Cyanobacteria $(17.2 \%)$ and Zygnemaphyceae $(14.0 \%)$ were with highest number of species at Choklyovo swamp.

Similar community structure had Skala 2 Lake: Chlorophyceae $(24.1 \%)$, Cyanobacteria $(17.8 \%)$ and Bacillariophyceae (17.0\%). Different dominant taxa were registered at Skala 1: Cyanobacteria (27.7\%), Chlorophyceae $(22.9 \%)$ and Bacillariophyceae $(17.0 \%)$. 
Table 2. Ecological status assessment of studied lakes.

\begin{tabular}{|c|c|c|c|c|c|c|c|c|c|c|}
\hline & \multicolumn{2}{|c|}{ Arkutino } & \multicolumn{2}{|c|}{ Velyov vir } & \multicolumn{2}{|c|}{ Choklyovo swamp } & \multicolumn{2}{|c|}{ Skala 1} & \multicolumn{2}{|c|}{ Skala 2} \\
\hline & 2011 & 2012 & 2011 & 2012 & 2011 & 2012 & 2011 & 2012 & 2011 & 2012 \\
\hline \multicolumn{11}{|l|}{ Phytoplankton } \\
\hline Catalán Index (CI) & 1.1 & 0.4 & 1.1 & 0.77 & 0.85 & 0.6 & 61.0 & 1.65 & 0.95 & 0.38 \\
\hline Biomass $\left(\mathrm{mg} \cdot \mathrm{L}^{-1}\right)$ & 15.1 & 19 & 27.4 & 7.1 & 0.68 & 0.5 & 34 & 3.6 & 1.4 & 2.4 \\
\hline $\mathrm{Chl}$ a $\left(\mathrm{mg} \cdot \mathrm{L}^{-1}\right)$ & 27.8 & 41.8 & 56.7 & 12.6 & $<1$ & 1.7 & 73 & 7.4 & 2.8 & 5 \\
\hline $\mathrm{SD}(\mathrm{m})$ & $\mathrm{na}^{*}$ & 0.34 & 0.54 & 0.28 & $>2.5$ & $>2.5$ & 1.3 & 1.6 & 1.7 & 2.4 \\
\hline$\%$ Cyanobacteria & 0.1 & 0.4 & 0.6 & 0.6 & 2.3 & 0.2 & 64.9 & 13.3 & 2.6 & 1.8 \\
\hline Blooming species & $\begin{array}{c}\text { I degree: } \\
\text { Eu } \\
\text { II degree: } \\
\text { Di, } \mathrm{Eu}\end{array}$ & $\begin{array}{l}\text { I degree: } \\
\text { Di, Eu; } \\
\text { II degree: } \\
\text { Di, Eu }\end{array}$ & $\begin{array}{c}\text { II degree: } \\
\text { Eu III } \\
\text { degree: } \\
\text { Eu }\end{array}$ & $\begin{array}{c}\text { I degree: } \\
\text { Ba, Eu; } \\
\text { II degree: } \\
\text { Eu }\end{array}$ & 0 & 0 & $\begin{array}{l}\text { III } \\
\text { degree: } \\
\text { Cy }\end{array}$ & 0 & 0 & $\begin{array}{c}\text { I degree: } \\
\mathrm{Di}\end{array}$ \\
\hline Toxic species & 0 & 0 & 0 & 0 & $\begin{array}{l}\text { Rare: } \\
\text { M.a. }\end{array}$ & $\begin{array}{l}\text { Rare: } \\
\text { M.a., } \\
\text { M.w. }\end{array}$ & $\begin{array}{l}\text { M.a., } \\
\text { M.w., A }\end{array}$ & $\begin{array}{l}\text { M.a., } \\
\text { M.w. }\end{array}$ & $\begin{array}{l}\text { Single: } \\
\text { M.a., A }\end{array}$ & $\begin{array}{l}\text { Single: } \\
\text { M.a }\end{array}$ \\
\hline Macrophytes-EQR & 0.67 & 0.67 & 0.52 & 0.52 & 0.83 & 0.87 & 0.07 & 0.07 & 0.7 & 0.7 \\
\hline \multicolumn{11}{|l|}{ Macroinvertebrates } \\
\hline$\%$ Oligochaeta & 1.07 & 3 & $\mathrm{na}^{* *}$ & $\mathrm{na}^{* *}$ & 0 & 0.05 & 34 & 4 & 28.6 & 10 \\
\hline BI & 4 & 4.5 & 2 & 2.5 & 4 & 3.5 & 4.5 & 3.5 & 4 & 4.5 \\
\hline PETI & 0.6 & 0.86 & 0.18 & $\mathrm{na}^{* *}$ & 0.30 & 0.22 & 0.69 & 0.99 & 0.17 & 0.87 \\
\hline Number of taxa & 31 & 26 & 7 & 3 & 22 & 16 & 19 & 11 & 17 & 16 \\
\hline Individuals per $\mathrm{m}^{2}$ & 172 & 219 & 17 & 8 & 478 & 85 & 650 & 413 & 171 & 31 \\
\hline $\begin{array}{c}\text { Indicative ecological } \\
\text { status }\end{array}$ & High & High & Poor & Moderate & High & Good & High & Good & High & High \\
\hline
\end{tabular}

*Not measured (very shallow and covered with macrophytes); ${ }^{* *}$ Inability to calculate. Legend: SD: Transparency/Secchi disc reading; Cy: Cyanobacteria; Ba: Bacillariophyceae; Eu: Euglenophyceae; Di: Dinophyceae; M.a.: Microcystis aeruginosa; M.w.: Microcystis wesenbergii; A: Aphanizomenon flos-aquae; EQR: Ecological Quality Ratio; BI: Biotic Index; PETI: Potamal Trophic Index. Colors: blue — high status; green — good; yellow—moderate; orange—-poor; red—-bad.

Toxic species Cyanobacteria (Microcystis aeruginosa (Kütz.) Kütz., M. wesenbergii (Kom.) Kom. in Kondr. and Aphanizomenon flos-aquae (L.) Ralfs) were incidentally recorded in qualitative samples from Choklyovo swamp and Skala 2, while they had more pronounced presence at Skala 1 samples (Table 2).

The metric biomass ranged broadly from 0.5 to 34.0 $\mathrm{mg} \cdot \mathrm{L}^{-1}$ (Figure 2(D)). The average values for 2 years showed lower biomass at Choklyovo swamp $\left(0.6 \mathrm{mg} \cdot \mathrm{L}^{-1}\right)$ and Skala $2\left(1.9 \mathrm{mg} \cdot \mathrm{L}^{-1}\right)$. Skala 1 Lake biomass was one order higher due to intense III degree bloom of blue-green algae Anabaena spiroides Kleb during 2011, when the average seasonal biomass reached $34 \mathrm{mg} \cdot \mathrm{L}^{-1}$ (Table 2). Additionally bloom species with I degree intense was recorded during 2012 at Skala 2-dinoflagellate algae Peridinium lomnickii Wolosz. No blooming species were registered at Choklyovo swamp. The percentage biomass allocation among taxonomic groups indicated specificity based on lake and year of observation (Figure 2(D)). Blue-green algae dominance $(64.9 \%)$ in biomass at
Skala 2 during 2011 was a result of $A$. spiroides bloom. Such dominance of dinoflagellates was assessed at Choklyovo swamp during 2012 (63.0\%) and Skala 2 during $2012(43.4 \%)$.

Skala 1 Lake was distinguished from the rest semimountains lakes by the percent Cyanobacteria (Table 2). Eutrophic cyanobacteria covered significant percent from the total biomass at Skala 1: between $13.3 \%$ to $64.9 \%$, while \% Cyanobacteria was low and considerably constant at Skala 2 and Choklyovo swamp (0.2 - 2.6\%). Transparency was highest at Choklyovo swamp $(>2.5 \mathrm{~m})$ and ranged from 1.3 to $2.4 \mathrm{~m}$ at the rest two semi-mountain lakes.

\subsection{Macrophytes}

A total of 34 macrophyte species were recorded: 27 vascular plants, 6 bryophytes and 1 Chara species. Ceratophyllum demersum L. was registered at all lakes, except Skala 1, every year. Choklyovo swamp supported the richest macrophyte diversity (16 taxa) with Chara sp. 
and Potamogeton natans L. as dominant and deepest species. Thirteen species were registered at both Arkutino and Velyov vir lakes, with stands covering the whole lake surface. Ceratophyllum submersum L. and Salvinia natans (L.) all dominated macrophyte community at Arkutino Lake, while the observed dominant species at Velyov vir were six: Nymphaea alba L., Ceratophyllum submersum, C. demersum, Spirodella polyrhiza (L.) Schleid., Salvinia natans and Riccia fluitans L. Species-poor macrophyte community was dominated by Elodea-species at Skala 1 Lake, respectively by Potamogeton natans and Myriophyllum spicatum L. at Skala 2. The vegetation limit at Choklyovo swamp was $2 \mathrm{~m}$, respectively 1.1 and 3.8 at Skala 1 and Skala 2 lakes.

Only Choklyovo swamp was assessed in high ecological status based on macrophytes (Table 2). The rest of the studied natural lakes were in good status, except Skala 1 evaluated in poor status.

\subsection{Macroinvertebrates}

At this stage, ecological assessment of studied lakes through MZB is based on a system that is still being developed and further refined. According expert judgment leading in assessment is biotic index (BI) for rivers, which is adjusted for standing waters. Supporting role has total number of taxa, \% Oligochaeta and PETI.

In both years of study, Arkutino Lake was characterized with greatest species diversity than the other studied standing water bodies (Table 2). The structure of macrozoobenthos is dominated of the mayfly (genus Cloeon, Caenis), chironomid midge larvae (Chironomus sp.) true bugs (Plea sp.), water beetles, and dragonfly larvae as well water oligochaetes represented mainly by tubificid and naidid worms. Trophic index value characterized trophic structure of benthic community as stable and balanced.

Unfavourable environmental conditions (critically low water levels, low oxygen concentrations, anaerobic conditions) registered at Velyov vir, formed species-poor benthic community. While in 2011 were found seven species, in 2012, only 3 - one mayfly (Cloeon dipterum), one heteroptera (Hydrometra stagnorum) and one phantom midge (Chaoborus crystallinus) were established. The trophic sructure was completely destroyed. BI determined poor ecological status in 2011, which was slightly improved during the second year (Table 2).

Environmental situation in Choklyovo swamp determined by MZB differs during the two studied years. In 2011, benthic communities were characterized with great species diversity. Cloeon dipterum (Ephemeroptera), Chironomus gr. plumosus (Chironomidae, Diptera) and Enallagma cyathigerum (Odonata) were dominant species. An evaluation based on the number of taxa and BI determined high status of the studied water body. Never- theless, the trophic index showed imbalanced trophic structure. In 2012, BI value determined Choklyovo swamp in good condition. The extinction of the fish fauna recorded during the spring of the same year, probably led to a weak negative change in the ecological situation. That reflected adversely on the more sensitive trophic structure, which was destroyed.

Skala 1 Lake was characterized by a large number of individuals, mainly due to the invasion of the zebra mussel Dressena polymorpha. The leading in assessment BI indicated a change in the ecological status from high (2011) to good (2012). The trophic index PETI demonstrated almost maximum value in 2012 (Table 2). The reason for this discrepancy in the estimates was determined by the near-total dominance of filtrator Dreissena polymorpha, whose presence formed $93 \%$ of the total number of macrozoobenthos.

In both studied years macroinvertebrates communities in Lake Skala 2 were described with large taxonomic richness. The lake was characterized in good ecological status. Thus, although the modified nature of the water body, it was determined to be in reference conditions for the semi-mountain national type. The low value of PETI, established in 2011 was a result of the prevalence of trophic group scrapers, where the gastropod Physella acuta showed the largest number of individuals.

\section{Discussion}

\subsection{Physico-Chemistry}

The primary nutrients - nitrogen and phosphorus were highest in water samples from Velyov vir, followed by Arkutino Lake (Table 1). Both studied lowland lakes are specific shallow ecosystems with a layer of mud rich in organic matter. The assessed phosphorous enrichment above reference criteria at both lowland lakes could be linked to the decomposition of cattail (Typha spp.) and other helophytes, growing in abundance in studied lakes. Semi-mountain lakes fulfilled reference criteria. Choklyovo swamp had accelerated COD levels, character for lowland lakes. Skala 1 and Skala 2 lakes are in a close proximity to one another (500 $\mathrm{m}$ distance) and are hydraulically connected. Except fish stocking and recreational fishing, other anthropogenic activities were not recognized.

\subsection{Phytoplankton}

Large number of species, high total biomass and Euglenophyceae dominance were assessed in both lowland lakes. Euglenoids are dominants in algal communities of shallow lakes rich in organic matter [24-26] and are found to be vitamin B1 and B12 auxotrophs [27]. In addition, Euglenoids are mixotrophic and form cysts for survival in unfavorable conditions [28]. 
Ecological status assessment based on phytoplankton metrics was considerably different (Table 2). Seasonal values of biomass and chlorophyll $a$ revealed poor status of Arkutino Lake, while bloom intense of Euglenoids and Dinoflagellate (I, II degree) indicated moderate status. Velyov vir was in bad status during 2011 based on biomass, chlorophyll $a$ and III degree Euglenoids blooms. Improvement of ecological conditions was assessed during the next year, i.e. metrics biomass and blooms degree determined moderate status. Nevertheless, metrics reflecting presence and relative abundance of eutrophic blue-green algae (toxic species and \% Cyanobacteria), indicated higher status and reference conditions. Catalán Index values also ranged between high and good status. Thus we consider that the above three metrics are not reliable in such shallow and organic-rich lakes, since they assess mainly eutrophication.

The discussed contradictory results indicated that specific approach is needed for assessment of shallow and rich in organic matter lakes. Class boundaries of transparency, biomass, chlorophyll $a$ and application of alternative phytoplankton index should be considered.

Only Choklyovo swamp was in reference conditions among three studied semi-mountains lakes based on all applied phytoplankton metrics (Table 2). High species number, low biomass and lack of blooms were recorded during both years of observations.

Skala 2 Lake was between high и good status during 2 years. Reference conditions were assessed at 2011 except for transparency $(1.7 \mathrm{~m})$. A slight deviation was established during the second year: I degree bloom of dinoflagellate algae Peridinium lomnickii, which reflected the average seasonal biomass $\left(2.4 \mathrm{mg} \cdot \mathrm{L}^{-1}\right)$ and chlotophyll $a$ $\left(5 \mu \mathrm{g} \cdot \mathrm{L}^{-1}\right)$.

Despite connection with Skala 2, Skala 1 Lake is completely different and isolated ecosystem with specific species composition and dominant taxa. Skala 1 had twice lower number of species (36) with highest bluegreen algae portion in species richness (33.9\%). A number of eutrophic toxic blue-green algae were recorded: $A$. spiroides, A. flos-aquae, M. aeruginosa, M. wesenbergii. Exceptionally high percent of eutrophic Cyanobacteria in the total biomass $(64.9 \%)$ indicated bad status, supported by the values of Catalán Index, biomass and chlorophylla a. According to the functional classification of the freshwater phytoplankton after Reynolds et al. [24] A. spiroides belongs to the assemblage $\mathrm{H} 1$, which integrated dinitrogen-fixing Nostocaleans - character for epilimnion of eutrophic stratified lakes with low nitrogen content [26]. Our results for total nitrogen at Skala 1 Lake confirmed A. spiroides preference of such conditions. Such prolonged blue-green algae blooms are character for eutrophicated lakes [29]. Due to the lack of significant anthropogenic pressure, the eutrophic state of Skala 1 dur- ing 2011 was presumed to be related to sudden gases discharge. The tectonic lake morphometric data for the last 100 years illustrated accelerated succession and progressive decrease in area [30].

\subsection{Macrophytes}

Macrophyte community composition, dominant species and vegetation limit of the studied lakes clearly reflected the assessed ecological status, in particular the response of the vegetation to nutrient enrichment and anthropogenic influence.

Type specific reference species (Potamogeton natans and Chara spp.) dominance in rich macrophyte community at Choklyovo swamp reflected lake high ecological status. However, degradation indicators and invasive species Elodea canadensis and E. nuttallii were regularly recorded. Both species could indicate an initial eutrophication process and were recognized to be involved in mass developments [31], thus should be further monitored.

The assessed good status of Arkutino and Velyov vir lakes was a result of abundant indifferent taxa, while sensitive species (Riccia fluitans, Hydrocharis morsusranae) were with lower quantities. Salvinia natans was among dominant indifferent species (together with Ceratophyllum submersum, C. demersum, Nymphaea alba, etc.) and could be suggested as a useful tolerant indicator.

Deep macrophyte stands of dominant Potamogeton lucens, $P$. natans, Myriophyllum spicatum illustrated good status of Skala 2 Lake. Elodea canadensis was registered in low percent share (up to $13 \%$ ) from the total macrophyte quantity within the depth $0-2 \mathrm{~m}$. In contrast, macrophyte community of Skala 1 Lake had between 83\% - 97\% Elodea spp. percent shares. The most serious problems recognized were the poor species composition and submerged macrophyte disappearance from depth zone above $1 \mathrm{~m}$. These findings could be related to the Cyanobacteria blooms in addition to gases discharge, since high macrophyte biomass was found to decrease the probability of algal blooms [32].

\subsection{Macroinvertebrates}

Arkutino and Skala 2 were characterized by high taxonomic richness, stable and well-balanced trophic structure, and presence of indicator taxa. Leading in assessment BI showed good ecological status of two water bodies. Based on MZB, both Arkutino and Skala 2 demonstrated a high potential for reference conditions or close to them, in accordance with Bulgarian classification system [18].

Despite the lack of anthropogenic impact, resulting in almost extreme adverse environmental conditions (dry, 
low oxygen concentrations, anaerobic conditions) Velyov vir did not show good ecological state, assessed through MZB. It should be noted that compared to 2011, in 2012 a slight improvement of the ecological situation was observed.

Unlike Velyov vir, Skala 1 Lake had decreased taxonomic richness. However, all tested indices, based on MZB ranged within high and good status.

In 2011, Choklyovo swamp was characterized with high number of taxa, high ecological status and definite reference conditions for marsh ecosystems. The dead of ihtiofauna recorded in the spring of 2012 influenced adversely benthic communities. This situation reflected negatively the evaluation based on MZB indices, which was changed from high to good ecological state.

\subsection{Integrated Assessment}

Studied lowland lakes (Velyov vir and Arkutino) are very shallow $(0.4-1 \mathrm{~m})$ with deep organic silt layer, extensively covered with macrophytes. Since lakes are located in the range of a reserve's territory, phytoplankton variations were considered as a result of natural processes such as decomposition, detritus precipitation, and strong seasonal water level fluctuations (i.e. decreasing with $0.6 \mathrm{~m}$ at Velyov vir Lake during 2011).

Based on the applied 3 biological quality elements (BQEs) Arkutino Lake could be evaluated in good ecological status during 2011-2012 and close to reference conditions, while Velyov vir was in moderate status (Table 2). It has to be underlined that these dynamic, shallow and naturally eutrophicated water bodies require specific approach in defining reference conditions and ecological status assessing.

Among semi-mountain lakes only Choklyovo swamp was in high ecological status based on all 3 BQEs during two years period. Skala 2 Lake as a slightly modified water body can be evaluated to be close to reference conditions and in high ecological potential. Only macrophytes resulted in good potential assessment. Skala 1 Lake was in poor status based on macrophytes, while phytoplankton assessment resulted in moderate status. Cyanobacteria blooms were registered during the first year of observation. There is not a good explanation about reasons for such Cyanobacteria blooms because of slight anthropogenic pressure. The most serious suggestion should be the influence of natural gases (hydrogen sulphide, etc.) coming from gasconductive faults of the East Stara Planina Mountain [33].

Most of the studied lowland lakes in Bulgaria are extremely specific water bodies because of the following grounds:

- Changeable water levels (some biological characteristics typical for temporary shallow lakes, Velyov vir and Arkutino);
- Peat-bog conditions (Choklyovo swamp);

- Gasconductive faults caused serious seasonal algae blooms (Cyanobacteria) (Skala 1 Lake).

All these conclusions refer to the natural variability of the reference conditions of Bulgarian lakes. There are many specific cases within the lake types with specific and unique condition that should be assessed in details before providing standardized classification systems in compliance with the requirements of Water Farmework Directive 2000/60/EC.

\section{REFERENCES}

[1] K. Ivanov, A. Sotirov, A. Rozhdestvenski and D. Vodenicharov, "The Lakes in Bulgaria," Trudove na Instituta po Hidrologiya i Meteorologiya, Vol. 16, 1964, pp. 1-240 (In Bulgarian).

[2] J. R. Karr, "Biological Integrity: A Long-Neglected Aspect of Water Resource Management," Ecological Applications, Vol. 1, No. 1, 1991, pp. 66-84. doi: $10.2307 / 1941848$

[3] European Union, "Directive 2000/60/EC of the European Parliament and of the Council of 23 October 2000 Establishing a Framework for Community Action in the Field of Water Policy," Official Journal of the European Communities, Vol. L327, 2000, pp. 1-72.

[4] G. A. Cole, "Textbook of Limnology," Waveland Press, Illinois, 1994.

[5] C. Van Den Hoek, D. G. Mann and H. M. Jahns, "Algae. An Introduction to Phycology," Cambridge University Press, Cambridge, 1995.

[6] J. Padisák, G. Borics, I. Grigorszky and E. Soróczki-Pintér, "Use of Phytoplankton Assemblages for Monitoring Ecological Status of Lakes within the Water Framework Directive: The Assemblage Index," Hydrobiologia, Vol. 553, No. 1, 2006, pp. 1-14.

doi:10.1007/s10750-005-1393-9

[7] H. Hillebrand, C.-D. Dürselen, D. Kirschtel, U. Pollingher and T. Zohary, "Biovolume Calculations for Pelagic and Benthic Microalgae," Journal of Phycology, Vol. 35, No. 2, 1999, pp. 403-424. doi:10.1046/j.1529-8817.1999.3520403.x

[8] R. G. Wetzel and G. E. Likens, "Limnological Analyses," Springer-Verlag New York Inc., New York, 2000.

[9] J. Schaumburg, C. Schranz, D. Stelzer and G. Hofmann, "Action Instructions for the Ecological Evaluation of Lakes for Implementation of the EU Water Framework Directive: Makrophytes and Phytobenthos," Bavarian Environment Agency, Bavarian, 2007.

[10] R. Grolle and D. G. Long, "An Annotated Check-List of the Hepaticae and Anthocerotae of Europe and Macaronesia," Journal of Bryology, Vol. 22, 2000, pp. 103140.

[11] M. O. Hill, N. Bell, M. A. Bruggeman-Nannenga, M. Brugués, M. J. Cano, J. Enroth, K. I. Flatberg, J.-P. Frahm, M. T. Gallego, R. Garilleti, J. Guerra, L. Hedenäs, D. T. Holyoak, J. Hyvönen, M. S. Ignatov, F. Lara, V. Mazimpaka, 
J. Muñoz and L. Söderström, “An annotated checklist of the mosses of Europe and Macaronesia," Journal of Bryology, Vol. 28, No. 3, 2006, pp. 198-267. doi:10.1179/174328206X119998

[12] T. G. Tutin, N. A. Burges, A. O. Chater, J. R. Edmondson, V. H. Heywood, D. M. Moore, D. H. Valentine, S. M. Walters and D. A. Webb, "Flora Europaea," Cambridge University Press, Cambridge, pp. 1964-1980.

[13] T. G. Tutin, N. A. Burges, A. O. Chater, J. R. Edmondson, V. H. Heywood, D. M. Moore, D. H. Valentine, S. M. Walters and D. A. Webb, "Flora Europaea," Cambridge University Press, Cambridge, 1993.

[14] A. Kohler, "Methoden der Kartierung von Flora und Vegetation von Süßwasserbiotopen," Landschaft \& Stadt, Vol. 10, No. 2, 1978, pp. 73-85.

[15] S. Cheshmedjiev, R. Soufi, Y. Vidinova, V. Tyufekchieva, I. Yaneva, Y. Uzunov and E. Varadinova, "Multi-Habitat Sampling Method for Benthic Macroinvertebrate Communities in Different River Types in Bulgaria," Water Research and Management, Vol. 1, No. 3, 2011, pp. 5558.

[16] K. Pall and V. Moser, "Austrian Index Macrophytes (AIMModule 1) for Lakes: A Water Framework Directive Compliant Assessment System for Lakes Using Aquatic Macrophytes," Hydrobiologia, Vol. 633, No. 1, 2009, pp. 83104. doi:10.1007/s10750-009-9871-0

[17] J. Catálan, M. Ventura, A. Munné and L. Godé, "Desenvolupament d'un Index Integral de Qualitat Ecològica i Regionalització Ambiental dels Sistemes Lacustres de Catalunya," Agencia Catalana del Aigua, Generalitat de Catalunya, 2003.

[18] S. Cheshmedjiev, R. Mladenov, D. Belkinova, G. Gecheva, I. Dimitrova-Dyulgerova, P. Ivanov and S. Mihov, "Development of Classification System and Biological Reference Conditions for Bulgarian Rivers and Lakes According to the Water Framework Directive," Biotechnology and Biotechnological Equipment, Vol. 24, No. 2SE, 2010, pp. 155-163.

[19] G. Gecheva, I. Dimitrova-Dyulgerova and S. Cheshmedjiev, "Macrophytes," In: Y. Uzunov, Ed., Biological Analysis and Ecological Status Assessment of Bulgarian Surface Water Ecosystems, University of Plovdiv Publishing House, Plovdiv, 2013, pp. 127-146 (In Bulgarian).

[20] K. J. Clabby and J. J. Bowman, "Report of Irish Participants," In: P. F. Ghetti, Ed., 3rd Technical Seminar on Biological Water Assessment Methods, Commission of the European Communities, Parma, 1979.

[21] K. J. Clabby, "The National Survey of Irish Rivers: A Review of Biological Monitoring," An Foras Forbartha, Dublin, 1981.

[22] S. Cheshmedjiev and E. Varadinova, "Macrozoobenthos," In: Y. Uzunov, Ed., Biological Analysis and Ecological Status Assessment of Bulgarian Surface Water Ecosystems, University of Plovdiv Publishing House, Plovdiv, 2013, pp. 147-163 (In Bulgarian).
[23] H. Schweder, "Neue Indices fur die Bewertung des Okologischen Zustandes von Fließgewassern, abgeleitet aus der Makroinvertebraten-Erna“hrungstypologie," Limnologie Aktuell, Vol. 3, 1992, pp. 353-377.

[24] C. S. Reynolds, V. L. M. Huszar, C. Kruk, L. NaselliFlores and S. Melo, "Towards a Functional Classification of the Freshwater Phytoplankton," Journal of Plankton Research, Vol. 24, No. 5, 2002, pp. 417-428. doi:10.1093/plankt/24.5.417

[25] J. Padisák, G. Borics, G. Fehér, I. Grigorszky, I. Oldal, A. Schmidt and Z. Zámbóné-Doma, "Dominant Species, Functional Assemblages and Frequency of Equilibrium Phases in Late Summer Phytoplankton Assemblages in Hungarian Small Shallow Lakes," Hydrobiologia, Vol. 502, No. 1-3, 2003, pp. 157-168. doi:10.1023/B:HYDR.0000004278.10887.40

[26] J. Padisák, L. O. Crossetti and L. Naselli-Flores, "Use and Misuse in the Application of the Phytoplankton Ffunctional Classification: A Critical Review with Updates, $\mathrm{Hy}$ drobiologia, Vol. 621, No. 1, 2009, pp. 1-19. doi:10.1007/s10750-008-9645-0

[27] R. G. South and A. Whittick. "Introduction to Phycology," Mir, Moscow, 1990.

[28] C. Kruk, V. L. M. Huszar, E. T. H. M. Peeters, S. Bonilla, L. Costa, M. Lürling, C. S. Reynolds and M. Scheffer, "A Morphological Classification Capturing Functional Variation in Phytoplankton," Freshwater Biology, Vol. 55, No. 3, 2010, pp. 614-627. doi:10.1111/j.1365-2427.2009.02298.x

[29] I. S. Trifonova, "Lake Phytoplankton Seasonal and Basic Succession," Hydrobiological Journal, Vol. 22, 1986, pp. 21-29 (in Russian).

[30] M. Stoyneva and T. Michev, "Skalensko Ezero," In: T. Michev and M. Stoyneva, Eds., Inventory of Bulgarian Wetlands and their Biodiversity. Part 1: Non-Lotic Wetlands, Publishing House Elsi-M, Sofia, 2007.

[31] S. Hilt, E. M. Gross, M. Hupfer, H. Morscheid, J. Mählmann, A. Melzer, J. Poltz, S. Sandrock, E.-M. Scharf, S. Schneider and K. van de Weyer, "Restoration of Submerged Vegetation in Shallow Eutrophic Lakes-A Guideline and State of the Art in Germany," Limnologica, Vol. 36, 2013, pp. 155-171. doi:10.1016/j.limno.2006.06.001

[32] E. S. Bakker, E. Van Donk, S. A. J. Declerck, N. R. Helmsing, B. Hidding and B. A. Nolet, "Effect of Macrophyte Community Composition and Nutrient Enrichment on Plant Biomass and Algal Blooms," Basic and Apllied Ecology, Vol. 11, No. 5, 2010, pp. 432-439. doi:10.1016/j.baae.2010.06.005

[33] M. Paskalev, V. Hristov and P. Petrov, "Gasconductive Faults of the East Stara Planina Mountain (between Beronovo Village and Sungurlare Town)," Proceedings of the National Conference with International Participation Geosciences, Sofia, 3-4 December 2009, pp. 77-78 (In Bulgarian). 